\title{
LA PRENDA SIN DESPLAZAMIENTO \\ DE CRÉDITOS NOMINATIVOS \\ EN EL DERECHO CHILENO*
}

NON-POSSESSORY PLEDGE

OF NOMINATIVE RECEIVABLES

IN CHILEAN LAW

\section{O PAGAMENTO DA GARANTIA SEM DESLOCAMENTO DE CRÉDITOS NOMINATIVOS NO DIREITO CHILENO}

Alejandro Guzmán Brito**

\section{RESUMEN}

La nueva regulación de la prenda sin desplazamiento, contenida en el artículo 14 de la ley $\mathrm{N}^{\circ} 20.190$, hace posible su aplicación a los créditos nominativos, con algunas singularidades frente al régimen general de tal prenda, las cuales son el tema del presente trabajo.

Palabras claves: prenda sin desplazamiento, prenda de créditos, prenda sin desplazamiento de créditos nominativos.

\section{AbStRact}

This paper addresses differences in the application to nominative receivables in the new regulation on non-possessory pledges contained in Article 14 of Law 20.190.

* Este trabajo hace parte del proyecto patrocinado por FONDECYT bajo el número 1095068.

** Doctor en Derecho, Universidad de Navarra, España; profesor titular de Derecho Romano de la Facultad de Derecho de la Pontificia Universidad Católica de Valparaíso. Dirección postal: Facultad de Derecho, Pontificia Universidad Católica de Valparaíso, avenida Brasil 2950, Valparaíso, Chile. Artículo recibido el 6 de septiembre de 2010 y aceptado para su publicación el 15 de diciembre de 2010. Correo electrónico: aguzman@ucv.cl 
Keywords: Non-possessory pledge, Receivable pledge, Nominative receivable non-possessory pledge.

\section{Resumo}

A nova regulação do pagamento de garanti sem deslocamento, contida no artigo 14 da Lei $\mathrm{N}^{\circ}$ 20.190, faz possível sua aplicação aos créditos nominativos, com algumas singularidades diante do regime geral de tal garantia, as quais é a temática do presente trabalho.

Palavras chaves: Garantia sem deslocamento, Garantia de créditos, Garantia sem deslocamento de créditos nominativos.

\section{LA PRENDA CON DESPLAZAMIENTO RECAÍDA SOBRE CRÉDITOS Y LA AUTORIZACIÓN DE UNA PRENDA SIN DESPLAZAMIENTO SOBRE LOS CRÉDITOS NOMINATIVOS}

1. El artículo 7 contenido en el artículo 14 de la ley $\mathrm{N}^{\circ}$ 20.190, que Dicta 10 Normas sobre Prenda sin Desplazamiento y Crea el Registro de Prendas sin Desplazamiento ${ }^{1}$, autoriza el empleo de la prenda que estatuye con respecto a los créditos nominativos. En la actualidad, la pignoración de créditos en general es posible, siempre que consten en un título documental; pero esa prenda se encuentra sometida al régimen del desplazamiento, porque se perfecciona por la entrega del título.

a) Si la prenda de un crédito de dinero, de fungibles que no sean dinero o de especies muebles es, en efecto, civil, la operación queda sin más regida por el artículo 2389 del $C$ C.:

"Se puede dar en prenda un crédito entregando el título; pero será necesario que el acreedor lo notifique al deudor del crédito consignado en el título, prohibiéndole que lo pague en otras manos" ${ }^{2}$.

${ }^{1}$ Diario Oficial de 5 de junio de 2007. De acuerdo con el artículo 41 de la ley, ella misma debía entrar en vigencia noventa días contados desde la fecha en que se publicara el "Reglamento del Registro de Prenda sin Desplazamiento" en el Diario Oficial. La publicación tuvo lugar el 23 de octubre de 2010, así es que el plazo de vacación se extinguió a las 24:00 horas del día 21 de enero de 2011 y la ley entró en vigencia un instante después, ya iniciado el 22 de enero.

${ }^{2}$ El artículo 203 del Código de Aguas de 1982 (Diario Oficial de 29 de octubre de 1981) permite a las comunidades de aguas -y, por mandato de su artículo 258, también a las asociaciones de canalistas y a las otras organizaciones de usuarios de aguas- pignorar 
De la norma, en cuanto exige entregar el título, se infiere que si el crédito no consta en un título no es posible pignorarlo con desplazamiento, aunque el asunto se ha prestado a debate, del cual trataremos después ${ }^{3}$.

b) Cuando es mercantil la prenda de un crédito de dinero, de fungibles que no sean dinero o de especies muebles, y consta en un título que no sea de crédito, o que siéndolo lleva la cláusula de "no endosable", su pignoración no está sometida a un modo especial de perfeccionamiento, así que se celebra del mismo modo que la civil, por aplicación del artículo 2 del C. Com. ${ }^{5}$. Además, también es necesaria la notificación de la prenda al deudor del crédito, prohibiéndole que lo pague en otras manos, porque eso está expresamente dicho en el artículo $816 \mathrm{del} \mathrm{C}$. Com. y, aunque no lo dijera sería exigible por aplicación subsidiaria del artículo 2389 del $C C$.

La prenda mercantil de cosas corporales está sujeta, además, al dispositivo del general artículo 815 del C. Com.:

\begin{abstract}
"Para que el acreedor prendario goce del privilegio enunciado ${ }^{6}$ en concurrencia de otros acreedores, se requiere:/ $1^{\circ}$ Que el contrato de prenda sea otorgado por escritura pública o en documento privado protocolizado, previa certificación en el mismo de la fecha de esa diligencia, puesta por el notario respectivo; $/ 2^{\circ}$ Que la escritura o documento contenga la declaración de la suma de la deuda y
\end{abstract}

los créditos que haya contra sus miembros: "en garantía de préstamos que contraten las comunidades, con el objeto de obtener capital necesario para el cumplimiento de sus fines". Esta prenda es especial por el tipo de deudor y acreedor de la obligación pignorada y de la deuda garantizable con ella, y por su objeto; pero no en cuanto a su perfeccionamiento que se rige por las reglas generales, según que la prenda sea con o sin desplazamiento.

${ }^{3}$ Véase, más adelante, el capítulo II, d).

${ }^{4}$ De acuerdo con el artículo 18 de la ley $N^{\circ} 18.092$ (Diario Oficial de 14 de enero de 1982): "La letra, aún la no librada expresamente a la orden, es transferible por endoso. No obstante, si el librador ha insertado en la letra las palabras 'no endosable' o una expresión equivalente, sólo podrá transferirse o constituirse en prenda conforme a las reglas aplicables a los créditos nominativos. En todo caso, puede endosarse en comisión de cobranza". Por consiguiente, el endoso es aplicable a la letra nominativa y a la orden; y sólo queda excluido si se la declara "no endosable". En tal caso, el documento se rige por las reglas de los créditos nominativos.

${ }^{5}$ Artículo 2 del C. Com.: "En los casos que no estén especialmente resueltos por este Código, se aplicarán las disposiciones del Código Civil”.

${ }^{6} \mathrm{El}$ "privilegio enunciado" es el del artículo 814 del C. Com.: "El contrato de prenda confiere al acreedor el derecho de hacerse pagar con el valor de la cosa empeñada con preferencia a los demás acreedores del deudor". 
la especie y naturaleza de las cosas empeñadas, o que lleve anexa una descripción de su calidad, peso y medida"7.

Por mandato del artículo 816 del C. Com., esta norma también rige la prenda mercantil de créditos, pues dice:

"Lo dispuesto en el artículo anterior es aplicable a la prenda consistente en un crédito [...]".

El "artículo anterior", o sea, el 815, es el que dispone sobre el régimen de oponibilidad del privilegio prendario a los demás acreedores.

c) Si la prenda mercantil recae sobre un crédito de dinero que sí consta en un título de crédito, aunque no haya sido librado en forma expresa "a la orden", con tal que no se le haya añadido la cláusula de "no endosable", la pignoración del crédito debe ejecutarse merced a un "endoso en garantía", que se ciñe al artículo 21 de la ley $\mathrm{N}^{\mathrm{O}}$ 18.092. El endoso previsto en tal norma se halla literalmente referido a la letra de cambio, pero es aplicable al pagaré por mandato del artículo 107 de la misma ley; y a

"cualesquiera otros títulos de crédito de dinero emitidos con la cláusula 'a la orden', 'a favor de', 'a disposición de' u otras equivalentes, cualesquiera fuere la denominación con que se designare a dichos instrumentos",

${ }^{7}$ La exigencia de escritura pública o privada, contenida en este artículo, no añade el carácter de solemne al contrato real de prenda, toda vez que aquélla es sólo por vía de oponibilidad del privilegio a los demás acreedores. Esto se desprende con toda claridad del enunciado del artículo 815 del C. Com.: "Para que el acreedor prendario goce del privilegio enunciado en concurrencia de otros acreedores, se requiere [...]". No se trata, en consecuencia, del perfeccionamiento y validez de la prenda. Fabián ElORRIAGa, "La prenda de créditos nominativos en la nueva normativa de la prenda sin desplazamiento", en Carlos Pizarro Wilson (coordinador), Estudios de Derecho Civil, Iv: Jornadas Nacionales de Derecho Civil, Olmué, 2008, Santiago, LegalPublishing, 2009, p. 549, n. 1, cree, por el contrario, que el artículo 815 del C. Com.: "[...] hace de la prenda mercantil un contrato real y solemne a la vez, ya que no basta con la entrega de la cosa para que produzca los efectos que le son propios, sino que se requiere, además, el cumplimiento de las solemnidades indicadas". Si se entrega una cosa corporal en prenda mercantil y no se da cumplimiento al artículo 815 del C. Com, el pignoratario puede hacer realizar prenda y pagarse, si es el único acreedor; y también si hay otros, aunque después de pagados éstos, frente a los cuales carece de privilegio (y supuesto que alcance el precio de venta).

${ }^{8}$ Ley $\mathrm{N}^{\circ} 18.092$, artículo 18: "La letra, aun la no librada expresamente a la orden, es transferible por endoso". Como veremos, esta norma, aunque literalmente referida a la letra de cambio, es de aplicación general a todos los títulos de crédito. 
por prescripción del artículo 1 de la ley $\mathrm{N}^{\mathrm{o}}$ 18.552, que regula el tratamiento de los títulos de crédito ${ }^{9}$.

Dispone el citado artículo 21 de la ley $\mathrm{N}^{\circ} 18.092$ :

"El endoso [...]. Importa constitución en prenda cuando incluye la cláusula 'valor en prenda', 'valor en garantía' u otra equivalente".

Sus efectos aparecen regulados por el artículo 30 de la misma ley:

"El endoso en garantía faculta al portador para ejercer todos los derechos emanados de la letra, cobrarla judicial y extrajudicialmente y aplicar sin más trámite su valor al pago de su crédito, con obligación de rendir cuenta al endosante. Sin embargo, a menos que se establezca lo contrario, el endosante no responde de la aceptación o pago de la letra. Mientras el endosatario mantenga la letra en su poder, debe practicar todas las diligencias necesarias para conservar los derechos emanados de ella./ [Inciso $2^{\circ}$ ] El endoso hecho por el endosatario en garantía, sólo vale como endoso en cobro./ [Inciso $3^{\circ}$ ] La disposición del artículo 28 es aplicable al endoso en garantía" ${ }^{\prime 10}$.

2. Ahora bien, la prenda civil y la mercantil de créditos tienen en común exigir el desplazamiento, que se ejecuta merced a la entrega del título al pignoratario, sin perjuicio del endoso en ciertos casos. La ley $\mathrm{N}^{\mathrm{O}}$ 18.112, de 1982, que Dicta Normas sobre Prenda sin Desplazamiento ${ }^{11}$, no innovó en la materia, porque su articulo 4 inciso $2^{\circ}$ expresamente limitó la nueva figura de prenda a aquélla recayente sobre bienes corporales muebles. Los créditos muebles, entonces, como cosas incorporales que son, quedaron excluidos del ámbito de aplicación de esa ley; así que bajo su vigencia la situación de aquellos créditos con respecto a la materia siguió igual que antes. El artículo 14 de la ley $\mathrm{N}^{\mathrm{O}} 20.190$, que contiene una nueva normativa sobre la prenda sin desplazamiento, ya citado, vino a reformar tal estado de cosas, en cuanto su artículo 7 aplica la prenda sin desplazamiento que regula a los créditos muebles nominativos. De esta

${ }^{9}$ Diario Oficial, de 20 de septiembre de 1986.

${ }^{10} \mathrm{El}$ artículo 28 citado en el inciso $3^{\circ}$ dice: "La persona demandada en virtud de una letra de cambio no puede oponer al demandante excepciones fundadas en relaciones personales con anteriores portadores de la letra”.

${ }^{11}$ Diario Oficial, de 16 de abril de 1982. 
manera, es facultativo para las partes de la convención prendaria sobre un crédito mueble nominativo que conste en un título celebrarla con o sin su desplazamiento ${ }^{12}$.

\section{CARACTERES DEL CRÉDITO \\ OBJETO DE PRENDA SIN DESPLAZAMIENTO}

a) No hay necesidad de recalcar que el crédito pignorable sin desplazamiento debe ser mueble, porque la prenda de aquella especie no puede más que recaer sobre ese género de cosas, como lo dicen los artículos 1 y 5 de la nueva ley. Y tampoco merece un comentario especial que un crédito o derecho personal mueble es principalmente aquél merced al cual se debe una cosa corporal mueble, como lo explica el artículo 580 del $C C$. Por lo demás, el crédito que se trata de pignorar puede ser de dinero, de una cantidad de fungibles que no sean dinero o de un cuerpo cierto o especie mueble.

b) De acuerdo con el artículo 581 del $C C$., los hechos que se deben se reputan muebles; así que podría plantearse la cuestión de saber si es pignorable un derecho personal incidente sobre un hecho positivo o negativo debido - vale decir, sobre una obligación de hacer o de no hacer- como consecuencia del carácter mueble que le atribuye el artículo citado. La respuesta que se impone es negativa, no porque haya alguna prohibición de tal pignoración o porque ella adolezca de algún vicio de invalidez, mas en el sentido de ser inoperante o ineficiente. La funcionalidad de la prenda de un crédito radica en que éste pueda ser subastado y que con el dinero conseguido en el acto resulte pagada la deuda garantizada al acreedor; o en ser cobrado por éste y aplicado el dinero obtenido, si es que dinero era su objeto, al mismo pago, o en empezar a tener la especie mueble cobrada en prenda con desplazamiento, si una tal especie era el objeto. Pero nada de ello sería posible cuando se aceptara la prenda sobre el crédito a un

${ }^{12}$ Por consiguiente, el régimen general de la pignoración de créditos es el siguiente:

i) si no están documentados o titulados, no se pueden pignorar con desplazamiento ni sin él (como veremos después);

ii) si son nominativos y están documentados, sea simplemente sea en un título de crédito, se pueden pignorar con desplazamiento o sin él;

iii) si son endosables o al portador y están documentados, sea simplemente sea en un título de crédito, sólo se pueden pignorar con desplazamiento (mediante endoso y entrega o sólo mediante entrega). 
hecho debido: de su deudor sólo se puede conseguir la ejecución de tal hecho, o la autorización de ejecutarlo por otro a sus expensas o los perjuicios por la inejecución ${ }^{13}$, nada de lo cual es apto para satisfacer al acreedor de dinero o de una cosa.

Con todo, el artículo $5 \mathrm{~N}^{\circ} 14$ del Reglamento del Registro de Prenda sin Desplazamiento ${ }^{14}$ da por sentado que se pueden pignorar créditos de hacer y no hacer, el cual prescribe:

"En el caso de los derechos personales [...] deberá indicarse si se trata de una obligación de dar, hacer o no hacer y el objeto de la misma [...]".

La norma se refiere a la individualización del objeto pignorado en el contrato prendario y, como se ve, supone que éste puede corresponder a créditos ${ }^{15}$ de las clases dichas. Cabe prever que ella resultará inoperante de hecho.

c) El artículo 7 de la nueva ley ha limitado la aplicación de la prenda sin desplazamiento sólo a los créditos muebles nominativos. Eso excluye su aplicación a los créditos "a la orden" y "al portador", cuya pignoración, por consiguiente, aunque sea posible, lo es únicamente con desplazamiento o entrega del título al pignoratario y, además, por endoso a su favor en el caso de aquéllos "a la orden".

d) Puesto que la prenda de que tratamos no exige, por definición, el desplazamiento del título documental en que consta el crédito por su entrega al pignoratario, los créditos que no constan en un título escrito, en teoría, admiten esta forma de pignoración. Pero obsta el hecho de que, como veremos con detalle después, según el artículo 7 inciso $1^{\circ}$ de la nueva ley, la pignoración de un crédito exige la protocolización de una copia de su título y la exhibición de éste al deudor en el momento de notificarle la pignoración, lo cual, por cierto, supone que el crédito pignorado conste en un título documental. Como nada de aquello podría ser ejecutado con respecto a un crédito que carezca de un título así, la conclusión fuere que indirectamente no está permitida su pignoración sin desplazamiento.

${ }^{13}$ Artículo 1553 del $C C$.

${ }^{14}$ Publicado en el Diario Oficial de 23 de octubre de 2010.

${ }^{15}$ La expresión "derecho personal”, usada en el precepto, es sinónima de 'crédito' (artículo 578 del CC.). 
Se ha pensado, empero, que esta conclusión es incorrecta ${ }^{16}$. Sobre la base de que un crédito no documentado puede ser transferido por cesión sin necesidad de tener que entregar un inexistente título suyo -como lo sostienen la doctrina y la jurisprudencia-, resultaría inconsecuente que se impidiera una operación menor, como es la prenda del mismo crédito; así que las exigencias de protocolización y exhibición del título valdrían cuando lo pignorado sea un crédito que conste en un título, mas no en caso contrario.

Pero el sustento de esta doctrina puede ser puesto seriamente en duda.

Su fundamento es que la cesión de un crédito no documentado o no titulado es posible, porque la inexistencia del título impide la entrega material, pero no la simbólica ${ }^{17}$; y que, en tales circunstancias, con mayor razón es factible la prenda civil (o mercantil) de un crédito sin título, merced a una entrega simbólica del crédito ${ }^{18}$. Pero el artículo 2389 del CC. exige la entrega del título, no del crédito, así que lo posible de ser entregado de manera simbólica es aquél, no éste. Ahora bien, lo que no existe no puede ser entregado de ninguna manera, ni siquiera simbólicamente; de lo que resulta que no sean operables la cesión ni la prenda con desplazamiento de créditos sin título. La entrega de un título no es necesaria en la prenda sin desplazamiento; pero sí la protocolización y la exhibición de una copia del título. Si el crédito que se trata de pignorar carece de título, no serán posibles la protocolización ni la entrega de una copia suya; así que, para la ley, la prenda de un crédito no documentado es inviable. Lo cual no carece de razón, porque permitir lo contrario se presta a fraudes, como veremos mejor después ${ }^{19}$.

e) El régimen de pignoración sin desplazamiento de créditos nominativos fijado en el artículo 7 se aplica a los créditos presente y futuros. Es cierto que el artículo 9 de la ley contiene una norma sobre la pignoración de bienes o derechos futuros ${ }^{20}$; y que en los "derechos futuros" se comprenden, por cierto, los créditos futuros, que, a su vez, pueden ser nominativos. Pero esa norma no

${ }^{16}$ Elorriaga (n. 7), pp. 560-561.

${ }^{17}$ Por todos: René Abeliuk, Las obligaciones, $3^{\mathrm{a}}$ ed., Santiago, Editorial Jurídica de Chile, 1993, tomo II, No 1.055 , p. 867.

${ }^{18}$ Por todos, Manuel Somarriva, Tratado de las cauciones, $2^{\text {a }}$ ed., Santiago, Contable Chilena, 1983, No 247, p. 232.

${ }^{19}$ Más adelante, en el capítulo IV, 2, b).

${ }^{20}$ Sobre lo cual, véase Alejandro GuZmán BRITo, "La prenda sin desplazamiento de cosas corporales e incorporales futuras", en Revista de Derecho de la Pontificia Universidad Católica de Valparaíso, No 31, Valparaíso, $2^{\circ}$ semestre de 2008, pp. 221-254. 
establece un régimen especial para la pignoración de derechos (y bienes) futuros, y se limita a declarar un par de efectos de Derecho sustancial o de fondo, que igual hubieren sido deducidos por el intérprete a partir de los principios y reglas generales ${ }^{21}$. De ello concluimos que la pignoración de créditos nominativos futuros, en cuanto son créditos, se rige por el dispositivo del artículo 7, igual que los presentes; sin perjuicio de serles aplicable el artículo 9 en cuanto son futuros.

\section{LEGITIMACIÓN PARA PIGNORAR SIN DESPLAZAMIENTO UN CRÉDITO NOMINATIVO}

Todo crédito es una cosa incorporal (artículos 576 y 578 del $C C$.), por lo cual sobre ellos también hay una especie de propiedad mentada en el artículo 583 del $C C$., que se confunde con la titularidad del crédito y que solemos llamar cuasidominio ${ }^{22}$. Tal titularidad y cuasidominio corresponden al acreedor. Ahora bien, esa calidad envuelve, desde luego, al acreedor original, pero también a su cesionario, o al heredero del primero o del segundo, y al legatario del crédito, o a su heredero o a su cesionario. Como cada uno de ellos tiene la facultad de enajenar el crédito, cada uno de ellos puede pignorarlo (artículo 2387 del $C C$.). Si llegare a acaecer que un tercero que no sea el acreedor, entendido como se ha dicho, pignorare un crédito nominativo, el acreedor siempre podrá alegar la inexistencia del derecho real de prenda, invocando su titularidad sobre ese crédito, sin perjuicio de la validez del contrato prendario mismo; y cuando ocurriera que el pignorante de un crédito nominativo del cual no es acreedor adquiriere después su titularidad o el acreedor ratificare el contrato prendario de aquél, se entenderá constituido el derecho real de prenda sobre el crédito desde la fecha de su inscripción en el Registro de Prendas sin Desplazamiento. Todo lo cual se desprende del artículo 13 de la nueva ley, una vez aplicado a los créditos su contenido.

${ }^{21}$ Artículo 9: "El contrato de prenda sobre bienes o derechos futuros será válido, pero mediante su inscripción no se adquirirá el derecho real de prenda sino desde que los bienes o derechos empeñados lleguen a existir. [Inciso $2^{\circ}$ ] Una vez que los bienes o derechos señalados en el inciso anterior existan, se entenderá constituido el derecho real de prenda desde la fecha de su inscripción en el Registro de Prendas sin Desplazamiento”.

${ }^{22}$ Sobre estos conceptos, véase Alejandro GuZMÁn BRITO, Las cosas incorporales en la doctrina y en el Derecho positivo, $2^{\text {a }}$ ed., Santiago, Editorial Jurídica de Chile, 2006, pp. 119-146. 


\section{Constitución de la PRENDA Sin DESPLAZAMiento} SOBRE CRÉDITOS NOMINATIVOS

De acuerdo con la nueva ley, la constitución de prenda sin desplazamiento sobre créditos nominativos se rige por las reglas generales dadas para constituir cualquier prenda de esa clase. Pero le ha añadido una regla especial. Por lo que atañe a las primeras, en esta sede no es necesario más que señalarlas de manera esquemática, porque hemos dedicado trabajos especiales al tema, con el añadido de alguna novedad introducida por el reglamento que aludiremos.

1. Por un lado, está, en efecto, la celebración de una convención solem$\mathrm{ne}^{23}$, que la ley llama contrato de prenda sin desplazamiento, mediante escritura pública o instrumento privado; en este último caso, las firmas de las partes concurrentes deben ser autorizadas por un notario y el instrumento mismo ser protocolizado en el registro del mismo notario que autorizó dichas firmas ${ }^{24}$. El artículo 3 de la nueva ley señala ciertas menciones que debe contener el documento prendario; de ellas interesa recordar aquí la de su $\mathrm{N}^{\circ} 3$, consistente en: "la individualización o la caracterización de las cosas empeñadas", que en la prenda de que tratamos se convierte, por cierto, en la individualización o la caracterización del crédito empeñado. Como un crédito se reconoce por su estructura y ésta viene dada por los sujetos, vale decir, las personas del acreedor y del deudor, su objeto jurídico y material y su causa (en el sentido de fuente), en la descripción circunstanciada de tales extremos ha de consistir la individualización o caracterización pedida por el artículo $3 \mathrm{~N}^{\circ} 3$ de la nueva ley.

a) Ahora bien, el artículo $5 \mathrm{~N}^{\circ} 14$ del Reglamento del Registro de Prenda sin Desplazamiento ${ }^{25}$ establece una regla especial de individualización de los créditos pignorados sin desplazamiento, enunciada en los siguientes términos:

"En el caso de derechos personales ${ }^{26}$ distintos de aquellos a los que se contienen en ${ }^{27}$ la letra de cambio, el pagaré o en otros títulos de créditos nominativos o endosables, deberá indicarse si se trata de

\footnotetext{
${ }^{23}$ Sobre ella, véase Alejandro GuZmán BRITo, "El llamado contrato de prenda sin desplazamiento", en Revista Chilena de Derecho Privado Fernando Fueyo Laneri, No 13, Santiago, diciembre de 2009, pp. 161-236.

${ }^{24}$ Todo en el artículo 2 de la nueva ley.

${ }^{25}$ Véase la n. 14.

${ }^{26}$ Véase la n. 15.

${ }^{27}$ Es clara la incorrección de la frase "derechos distintos de aquellos a los que se contienen en", que es o, bien: "derechos distintos de aquellos que se contienen en" o, bien: "derechos distintos de los que se contienen en".
} 
una obligación de dar, hacer o no hacer y el objeto de la misma, la fecha o tiempo en el cual deberá cumplirse la obligación y el acto jurídico donde consta esta última, sin perjuicio de los establecido en el artículo 3 número 2 de la ley".

El precepto exige, pues, que un crédito hecho recaer en prenda sin desplazamiento sea individualizado merced al señalamiento de los siguientes extremos:

i) si es de dar, hacer o no hacer el crédito;

ii) en todos los casos, cuál sea su objeto, se entiende que material, vale decir, la cosa, el derecho o el hecho de que se trate en cada caso;

iii) el día cierto o incierto, determinado o indeterminado para el cual se espera deber de cumplirse la obligación, lo cual la ley expresa con los vocablos 'fecha' y 'tiempo', así que en esto van incluidas las obligaciones a plazo y a condición;

iv) el "acto jurídico en donde consta" la obligación o crédito pignorado; lo cual debemos interpretar en el sentido de tener que referirse la fuente de que ella emana.

En esta enumeración reglamentaria de menciones se echa de menos la del deudor y el acreedor, que, con todo, no puede faltar, porque sin ella la obligación no queda, en realidad, individualizada. Pero se añade la indicación del día a que se sometió la obligación, lo que es del todo comprensible.

En su primera parte, la norma reconoce una excepción, por cuanto la manera de individualizar que describe no se aplica a los derechos personales o créditos contenidos en títulos de créditos -como la letra de cambio, el pagaré y otros-. La razón es que los extremos pedidos por el artículo $5 \mathrm{~N}^{\circ} 14$ del Reglamento, necesariamente ya constan en todo título de crédito, que documenta el acto jurídico-fuente de un crédito de dar siempre dinero a un día siempre cierto (no puede constituir condición), que se sabe cuál es porque está escrito o, si no, es a la vista, de guisa que la individualización resulta de esos solos hechos. Pero la excepción es aparente, ya que no se trata de que pueda omitirse la descripción del título de crédito mismo, porque el artículo $3 \mathrm{~N}^{\circ} 3$ de la ley ya la exige; sólo que, al individualizarse el título, se individualizan todos los extremos dichos.

Esta aparente excepción rige, según la norma reglamentaria, para los títulos de créditos nominativos o endosables. Pero esta última expresión es del todo incompetente, porque con ella se hace suponer a la norma la posibilidad general de pignorar sin 
desplazamiento un título de crédito endosable. Ahora bien, por definición, un crédito endosable es no-nominativo; pero el artículo 7 de la ley permite la pignoración sólo de créditos nominativos; así que tratándose de títulos endosables es toda la ley la inaplicable. Por lo mismo, tampoco se refiere ella a los títulos de crédito al portador $^{28}$. En síntesis, la norma se aplica a los derechos personales distintos de aquéllos que consten en títulos de crédito nominativos, únicos títulos que podrían ser pignorados sin desplazamiento.

b) El artículo $5 \mathrm{~N}^{\circ} 15$ del Reglamento contiene una regla especial aplicable esta vez a la pignoración de créditos consistentes en:

"derechos sociales que recaigan en sociedades colectivas civiles o comerciales, en sociedades de responsabilidad limitada, en comandita simple o en empresas individuales de responsabilidad limitada, o sobre cuotas de participación de cooperativas”.

Cuando tal sea el caso, se manda indicar en el contrato:

i) la razón social de la sociedad, cooperativa o empresa de que se trate, los derechos en la cual se pignoran;

ii) el nombre o razón social del socio o titular de los derechos 20 sociales que se pignoran;

iii) la proporción que representan tales derechos sobre el capital;

iv) el plazo de la sociedad y

v) cuando deba ser el caso, el número de inscripción de la cooperativa, sociedad o empresa a la que los derechos pignorados atañen, en el Registro de Comercio.

2. Por otro lado, se presenta la constitución del derecho real de prenda sin desplazamiento mismo ${ }^{29}$. De acuerdo con el artículo 25, la constitución y adquisición de tal derecho es efecto de la inscripción del contrato de prenda en el Registro de Prendas sin Desplazamiento, cuya gestión el artículo 28 pone a cargo del Servicio de Registro Civil e Identificación. Sin la inscripción, entonces, el derecho real no existe ni es, por consiguiente, oponible a nadie (artículo 25 inciso $1^{\circ}$ ).

${ }^{28}$ Los títulos de crédito al portador no están mencionados para la aparente excepción del artículo $5 \mathrm{~N}^{\circ} 14$ del Reglamento. Pero el intérprete debe cuidarse de deducir que tal omisión es indicativa de que los títulos al portador se rigen por la regla general de aquel artículo y constituyen, por ende, una suerte de contraexcepción, porque nada de la nueva ley les es aplicable.

${ }^{29}$ Acerca de él: Alejandro GuZmán Brito, "El derecho real de prenda sin desplazamiento", en Revista de Derecho de la Pontificia Universidad Católica de Valparaíso, No 34, Valparaíso, $1^{\mathrm{er}}$ semestre de 2010, pp. 101-159. 
3. Pero, como quedó adelantado, la nueva ley prescribe una peculiaridad relativa al contrato prendario sobre créditos nominativos, que se encuentra establecida en el segundo segmento del artículo 7 inciso $1^{\circ}$ :

“[...] Una copia del título que consigne el crédito nominativo que se otorgue en prenda será protocolizada al tiempo de suscribirse el contrato de prenda y en éste deberá hacerse mención de la protocolización de aquél".

El precepto contiene, en realidad, tres normas:

i) la de deberse protocolizar una copia del título en que se contenga el crédito nominativo pignorado,

ii) la de deberse ejecutar dicha protocolización al tiempo de suscribirse el contrato prendario y

iii) la de deberse mencionar la protocolización en el contrato prendario mismo.

a) Acaezca que este último haya de ser otorgado por escritura pública o, bien, por instrumento privado con sus firmas autorizadas ante un notario y protocolizado en el registro del mismo notario que autorizó dichas firmas, es necesaria la protocolización de una copia del título en que conste el crédito nominativo pignorado. Se observará, que cuando el contrato prendario es otorgado por instrumento privado, entonces debe haber dos protocolizaciones: la del instrumento contractual y la de la copia del título. La ley indica un momento para proceder a realizarlas, pero no un lugar. Dice que aquélla debe ser ejecutada "al tiempo de suscribirse el contrato"; pero no añade que deba tener lugar en el registro del mismo notario que autoriza la escritura pública o las firmas de quienes suscriben el instrumento privado contractual. De hecho, empero, es bien difícil -y antieconómico y peligroso intentarlo- que las partes suscriban la escritura pública o el instrumento privado del contrato prendario ante determinado notario y pidan la protocolización de una copia del título del crédito pignorado ante otro distinto: tal vez no haya tiempo ni sea posible la coordinación -sobre todo atendida la mención del trámite en el contrato mismo-; así que todo aconseja ejecutarlo ante el mismo notario que perfecciona la escritura pública o autoriza las firmas del instrumento privado; aunque si por ventura se lograre hacer la separación, no pueda reprocharse de inválida la operación.

Ejecutada la protocolización necesario es describir sus circunstancias en el contrato prendario: 
"y en éste [en dicho contrato] deberá hacerse mención de la protocolización de aquél [de la copia del título]”.

Podemos conectar esta exigencia con la mención general que el artículo $3 \mathrm{~N}^{\circ} 3$ pide haber en todo contrato prendario: "La individualización o la caracterización de las cosas empeñadas". Como, según dijimos, se cumple óptimamente con esta mención cuando se indica la causa o fuente del crédito pignorado, su objeto y sus partes acreedora y deudora, en la descripción de la causa o fuente, que, desde otro punto de vista, equivale al título, cabe indicar, enseguida, los datos de la protocolización de su copia.

b) Las tres exigencias contenidas en el segundo segmento del artículo 7 inciso $1^{\circ}$ de la nueva ley, en orden a protocolizar una copia del título del crédito pignorado al tiempo de suscribirse el contrato prendario y de mencionar esta gestión en el contrato mismo han sido establecidas por la ley para el valor del contrato en consideración a su naturaleza y no a la calidad o estado de las personas (artículo 1682 inciso $1^{\circ}$ del $C C$.), así que su omisión o irregularidad genera nulidad absoluta del contrato. No son, pues, formalidades de publicidad sancionadas con inoponibilidad. La razón es clara: la exigencia de protocolizar una copia del título concerniente al crédito pignorado, por más que cumpla una función de publicidad, como por lo demás acontece con casi todas las formalidades, no fue establecida en obsequio directo a esa función sino para la de evitar un fraude a los terceros acreedores, consistente en pignorar créditos inexistentes sobre cosas existentes, que conceden una preferencia prendaria recayente en final de cuentas sobre estas últimas. Supóngase que se urde la siguiente operación fraudulenta: el insolvente Ticio, dueño de cierto automóvil valioso, acuerda con su amigo Cayo que pignore a favor del amigo común Mevio, un supuesto crédito de Cayo contra Ticio sobre el automóvil, para garantizar un supuesto crédito de Cayo contra Mevio. La operación está encaminada a dejar el automóvil fuera del alcance de los numerosos acreedores de Ticio, merced al privilegio que la pignoración del crédito sobre el automóvil concede a Mevio. La exigencia de protocolizar el título del crédito de Cayo contra Ticio sobre el automóvil y de mencionar la protocolización en el contrato prendario entre Cayo y Mevio al menos ofrece la posibilidad de investigar la realidad de ese crédito a los terceros acreedores, para deshacer el fraude.

Añadamos, en fin, que la publicidad tutelada con la amenaza de inoponibilidad tampoco es la función directa ni principal de la triple exigencia 
en examen, porque aquélla se encuentra asegurada merced a otras formalidades. Está asegurada a favor del deudor, en efecto, por la notificación del contrato prendario y la exhibición del título del crédito pignorado (segmento primero del artículo 7 inciso $1^{\circ}$ ); y a favor de terceros, por la inscripción del contrato prendario en el Registro de Prendas sin Desplazamiento. Así las cosas, limitar la función de las triple exigencia del segmento segundo a la publicidad y sancionar sus defectos con inoponibilidad fuere excesivo y redundante ${ }^{30}$.

\section{CONVENiOS OpCiONALES de LA CONVENCiÓN SOBRE PRENDA DE CRÉDITOS NOMINATIVOS}

La nueva ley tipifica varios convenios que las partes pueden adoptar en forma opcional al suscribir una convención prendaria (o con posterioridad a ésta, pero con sus mismas solemnidades). Ellos se pueden introducir sin problemas en una convención de prenda sobre créditos nominativos, con excepción de algunos, con los cuales resulta incompatible el carácter incorporal del objeto de la prenda. Nos limitaremos a mencionar en uno $\mathrm{u}$ otro sentido tales convenios, sin abundar en su alcance, porque cada uno de ellos ha sido minuciosamente examinado en otro lugar ${ }^{31}$.

a) Son aplicables a la prenda de créditos los siguientes convenios:

i) de limitación de la garantía prendaria a una suma determinada o determinable de dinero o a una proporción de diversas obligaciones (artículo $3 \mathrm{~N}^{\mathrm{o}} 4$ );

ii) de no repignorar el crédito ya empeñado (artículo 17) ${ }^{32}$;

iii) de no enajenar (ceder) el crédito pignorado o de no imponerle gravámenes no prendarios (artículo 17)

iv) de fijación de cierto lugar donde deba mantenerse el crédito empeñado (artículo 19), cuando se atiende al título del mismo,

${ }^{30} \mathrm{El}$ problema de la naturaleza de las formalidades del segmento segundo y, por consiguiente, de la sanción procedente en caso de su quebrantamiento, fue planteado por ElorRiaga (n. 7), pp. 554-555. El autor, aunque considera discutible el punto, se inclina por la sanción de la nulidad absoluta.

${ }^{31}$ Véase el capítulo XI del trabajo citado en la n. 23, pp. 210-234.

${ }^{32} \mathrm{El}$ artículo 7 del Reglamento aclara que cuando se convino prohibición de gravar la cosa pignorada, lo que incluye, por cierto, la de repignorarla, el convenio puede estar o no sometido a un plazo de vigencia; y que cuando no se le fijó un plazo, la prohibición se extiende a todo el tiempo de vigencia de la deuda.

${ }^{33}$ Lo expresado en la nota anterior vale, mutatis mutandis, para el caso de prohibición de enajenar el crédito empeñado, según el artículo 7 del Reglamento. 
que, por ende, debe ser mantenido en determinado lugar, por ejemplo, en una empresa de depósito de valores;

v) sobre el modo de inspeccionar la prenda (artículo 20), cuando el convenio va nuevamente aplicado al título del crédito pignorado (artículo 20);

vi) de poderse ceder con la prenda el crédito caucionado por ella (artículo 38);

vii) sobre extensión de la responsabilidad del pignorante por la conservación del crédito empeñado a la culpa leve (artículo 18 de la ley en relación con el artículo 2222 inciso $1^{\circ}$ del $C C$.); viii) de no asignación de valor al conjunto de créditos pignorados como grupo de bienes de la misma clase o universalidad de hecho (inciso $1^{\circ}$ del artículo 11 ).

b) En cuanto al convenio de no utilización, reemplazo, transformación o enajenación de los componentes de un grupo de bienes de una misma clase o universalidades de hecho pignorados (artículo 11 inciso $1^{\circ}$ ), si ellos están constituidos por créditos, es sólo aplicable a la no enajenación, pero difícilmente a los demás extremos referidos, atendido su carácter físico, que no atañe a la incorporeidad de los derechos que se pignoran. Esto último vale también para el convenio de utilizar la cosa empeñada en una manera que se especifica (segundo segmento del artículo 19), puesto que no es predicable de los derechos la categoría del uso o de la utilización.

\section{INOPONIBILIDAD DE LA PIGNORACIÓN DE UN CRÉDITO NOMINATIVO A SU DEUDOR}

1. El efecto principal de la pignoración de un crédito es suspender al acreedor su natural legitimación pasiva en el pago y activa en el cobro $\mathrm{y}$ atribuirlas al pignoratario, que es quien, por ende, puede ahora recibir del deudor el pago o exigírselo válidamente, en sustitución del acreedor ${ }^{34}$.

${ }^{34}$ Es el efecto inmediato y natural de la prenda de créditos. Véase, por ejemplo, el artículo 2363 del $C C$. francés: "Après notification, seul le créancier nanti reçoit valablement paiement de la créance donnée en nantissement tant en capital qu'en intérêts”; o el artículo 2803 del $C C$. italiano: "Il creditore pignoratizio è tenuto a riscuotere, alla scadenza, il crédito ricevuto in pegno [...]". Para Chile, véase el artículo 21 de la ley $\mathrm{N}^{\circ} 18.092$, transcrito en el capítulo I,1,c). Cfr. el artículo 12 del decreto ley $\mathrm{N}^{\circ} 776$ (Diario Oficial, 22 de diciembre de 1925): "Si la prenda consistiere en un crédito por suma de dinero, el acreedor prendario deberá cobrarlo a su vencimiento conforme a las reglas generales del Derecho, entendiéndose representante legal del dueño del crédito para este efecto. 
Todo ello significa que el pago del deudor al acreedor no vale, sin que importe si fue el deudor quien lo ofreció y lo aceptó el acreedor; o si fue éste quien lo exigió y el deudor aceptó ejecutarlo. Tal es lo que se dice, aunque de mala manera, en el primer segmento del inciso $1^{\circ}$ del artículo 7 :

"La prenda de créditos nominativos deberá ser notificada al deudor del crédito pignorado, [...], prohibiéndole que lo pague en otras manos $[\ldots] "$.

La norma fue redactada teniendo a la vista el artículo 2389 del $C C$.:

"Se puede dar en prenda un crédito entregando el título; pero será necesario que el acreedor lo notifique al deudor del crédito consignado en el título, prohibiéndole que lo pague en otras manos".

Pero la frase: "prohibiéndole que lo pague en otras manos" es incompleta, pues no se dice en cuáles "otras manos" queda al deudor prohibido pagar. El enigma desaparece cuando se lee el artículo 2556 del Proyecto inédito de Código Civil:

"Se puede dar en prenda un crédito entregando el título; pero será necesario que el acreedor prendario notifique al deudor del crédito que se empeña, el acto por el cual se le ha dado en prenda, prohibiéndole que pague dicho crédito en otras manos que las del acreedor prendario" 35 .

La forma definitiva con que la norma comparece, que es la del artículo 2389 del $C C$., emerge ya en el artículo del mismo número perteneciente al Proyecto de Código Civil de $1855^{36}$, que el Congreso Nacional aprobó; de modo de resultar claro que esa forma definitiva fue concebida en alguna revisión operada con posterioridad al Proyecto inédito y sobre él mismo, y con anterioridad a la edición de 1855. En tales circunstancias, una de dos: o la expresión "que las del acreedor prendario", escrita en el artículo 2556 del "Proyecto inédito...", cayó por inadvertencia al revisarse la redacción de ese

Las cantidades que perciba las aplicará sin sujeción a las formalidades de los artículos anteriores, al pago de su propio crédito, si este fuere de igual naturaleza, y en seguida rendirá cuenta a su deudor". Este precepto considera al pignoratario como representante legal del deudor; lo que es erróneo. El pignoratario es un cesionario, aunque en garantía; y de ahí deriva su legitimación.

${ }^{35}$ Andrés Bello, Obras completas de don Andrés Bello, Santiago, impreso por Pedro G. Ramírez, 1890, tomo XIII: Proyecto Inédito de Código Civil, pp. 592-593.

${ }^{36}$ Proyecto de Código Civil, Santiago, Imprenta Nacional, noviembre de 1855, p. 624. 
artículo y formar el 2389 del Proyecto de 1855 o, bien, se la suprimió deliberadamente, porque la idea que expresa va sobrentendida. Pero está fuera de duda que no pudo haberse suprimido la expresión porque las "manos" en que se pensó no eran las del acreedor prendario, ¿qué otras podrían ser?

Como consecuencia del análisis precedente, la norma del artículo 7 inciso $1^{\circ}$ de la nueva ley hay que entenderla como si dijera:

"La prenda de créditos nominativos deberá ser notificada al deudor del crédito pignorado, [...], prohibiéndole que lo pague en otras manos 'que las del acreedor prendario",

que aquí mejor llamamos "pignoratario"; así que el pago en manos del acreedor no vale; es decir, no libera al deudor ni extingue su deuda, de guisa que el pignoratario puede exigirle el cumplimiento, no bien quepa al deudor repetir lo pagado contra el acreedor.

2. Esta eficacia de la pignoración de créditos, consistente en deslegitimar al deudor para pagar y al acreedor para recibir el pago está supeditada, sin embargo, a que el deudor conozca que el crédito por él pagado al acreedor había sido objeto de pignoración; así que su pago no vale cuando la conociera y vale en el caso contrario. Esta disciplina viene expuesta 26 por la ley con recurso a las nociones de oponibilidad e inoponibilidad. Cuando el deudor conoce la pignoración, ésta le es oponible y, por ende, su pago al acreedor no vale, de modo que ni se libera él ni se extingue la deuda; si la desconoce no le es oponible y el pago que ejecute al acreedor vale, así que se libera y extingue la obligación. En realidad, este punto de la oponibilidad de la prenda de un crédito nominativo a su deudor es el único al que se refiere la nueva ley, en función de modificar levemente las reglas civiles vigentes sobre la materia.

La ley entiende que el deudor conoce la prenda y se hace oponible en su contra en dos hipótesis:

i) cuando le es notificada (números 3 a 4 siguientes) y

ii) cuando la acepta (número 5).

3. Dice el primer segmento del inciso $1^{\circ}$ del artículo 7 :

"La prenda de créditos nominativos deberá ser notificada al deudor del crédito pignorado, judicialmente o por medio de un notario con exhibición del título, prohibiéndole que lo pague en otras manos, salvo que mediare su aceptación por escrito; y en caso contrario, le será inoponible [...]”.

a) Como se ve, la norma establece una carga de notificar la "prenda”. Esta última palabra es muy ambigua, por cuanto significa el 
contrato de prenda, la cosa constituida en prenda, el derecho real de prenda, la obligación a que queda sujeta la cosa y la garantía prendaria ${ }^{37}$. Pero en el contexto del artículo 7 inciso $1^{\circ}$ no cabe duda que el uso del término queda circunscrito al contrato y al derecho real; así que se trata de saber si lo que debe ser notificado es sólo el contrato, aunque no esté inscrito, la inscripción del contrato sin el contrato o ambos, vale decir, el contrato y la inscripción.

Desde un punto de vista lógico-exegético, debe darse por cierto que ya se cumple con la exigencia legal de "notificar la prenda al deudor" cuando se le notifica el contrato prendario, aun antes de su inscripción, puesto que "prenda" significa al menos "contrato de prenda". Pero tal resultado puede ser corroborado con apoyo en el dato que se alcanza después de examinar la función que cumple la formalidad consistente en la notificación al deudor.

Como quedará de manifiesto dentro de poco, esa función no es dar existencia a la pignoración, de guisa de constituir una solemnidad suya, porque el conocimiento que el deudor tenga de la operación no pertenece a su estructura dogmática. La verdadera función del acto es permitir la eficiencia práctica de la pignoración, atendido que, en efecto, puede ella frustrarse cuando el deudor del crédito empeñado paga a su acreedor (o sea, al pignorante), o al heredero o al cesionario de aquél, si los hay. Lo cual se evita cuando tales pagos resulten impedidos desde una óptica jurídica; en el entendido que esto sólo puede operar si se prohíbe formalmente al deudor hacerlos. Una tal prohibición sólo puede producir sus efectos cuando el deudor conoce la pignoración del crédito de que es deudor; y ello implica notificársela. Ahora bien, para llegar a conocer la pignoración, es suficiente que el deudor conozca el hecho de haberse celebrado el contrato prendario. Por el contrario, exigir que el contrato esté inscrito para que sea la inscripción (con o sin el contrato) la notificada, puede conducir a que el deudor pague de manera lícita en el tiempo intermedio entre el contrato y la inscripción, por más que lo haga cuando el crédito ya está contractualmente pignorado. En fin, la inscripción es un requisito que hace al derecho real, y la prohibición de pagar en otras manos no es una consecuencia de aquél sino del contrato, aunque por medio de la ley.

${ }^{37}$ Sobre estas acepciones, véase Alejandro GuZMÁn BRITO, "La indivisibilidad de la garantía prendaria e hipotecaria", en Carlos PIZARRo Wilson (coordinador), Estudios de Derecho Civil, IV: Jornadas Nacionales de Derecho Civil, Olmué, 2008, Santiago, LegalPublishing, 2009, pp. 511-515. 
Concluimos, pues, que la expresión "prenda de créditos nominativos" en el inciso $1^{\circ}$ del artículo 7 significa "contrato de prenda de créditos nominativos", de modo que aquello que debe ser notificado al deudor del crédito pignorado es precisamente el contrato de prenda, aun cuando no esté inscrito.

b) La notificación del contrato prendario es al deudor. Bajo tal expresión debe, empero, entenderse al deudor original; o a su heredero, si aquél falleció; o a su cesionario, cuando lo había cedido; o al heredero del cesionario; o al legatario de la deuda, o a su heredero. Cada uno de estos, en efecto, es "deudor" en su caso ${ }^{38}$.

c) La notificación del contrato prendario al deudor puede ser judicial o extrajudicial. La norma, en efecto, dice:

“[...] ser notificada al deudor del crédito pignorado, judicialmente o por medio de un notario".

El procedimiento judicial de notificación -que es no contencioso o voluntario- implica una instancia escrita, presentada, por regla general, por el pignorante, pero que también podría ser presentada por el pignoratario, ya que la ley nada exclusivo dice al respecto, y dirigida al juez competente, que es el de letras en lo civil del domicilio del pignorante ${ }^{39}$; una resolución suya, emitida de plano ${ }^{40}$, que dé lugar a la notificación; y la ejecución de ésta por un receptor judicial, bien personalmente, en la forma prevista por el artículo 40 del $C P C$., bien de acuerdo con el artículo 44 del $C P C$., en cumplimiento de los prescrito por el artículo 47 del mismo cuerpo legal ${ }^{41}$.

${ }^{38}$ Cfr. Elorriaga (n. 7), p. 556, n. 8, quien menciona el caso de muerte del deudor original.

${ }^{39} \mathrm{El}$ "interesado" en la notificación de la prenda al deudor es el pignorante, porque la gestión está destinada a impedir que el deudor pague en otras manos. En consecuencia, de acuerdo con el artículo $134 \mathrm{del} C O T$., su domicilio es el que fija la competencia relativa del juez.

${ }^{40}$ Artículo 824 del COT.

${ }^{41}$ Artículo 47 del CPC.: "La forma de notificación de que tratan los artículos precedentes [40 a 46] se empleará siempre que la ley disponga que se notifique a algunas persona para la validez de ciertos actos [...]'. La expresión 'validez' debe ser interpretada ampliamente, esto es, no sólo como alusiva a la existencia y al valor formales, mas también en cuanto a la eficacia y oponibilidad de alguna operación. Aunque la prenda de créditos vale sin la notificación al deudor, no le es oponible sin ella, así que respecto de aquél, en este sentido amplio, no vale. 
El procedimiento extrajudicial de notificación sólo exige la intervención de un notario que ejecute la notificación ${ }^{42}$ al deudor que tenga domicilio en su territorio de competencia ${ }^{43}$, a petición del pignoratario (o del pignorante).

d) La norma exige notificación con "exhibición del título" al deudor. Se ha planteado la duda consistente en saber si tal exhibición es exigible sólo cuando la notificación es ejecutada por un notario o también si es judicial y la ejecuta un receptor. La razón de dudar proviene de la ausencia de una "coma" después del vocablo 'notario', en la frase:

"deberá ser notificada al deudor del crédito pignorado, judicialmente o por medio de un notario con exhibición del título",

en contraste, por ejemplo, con la presencia de una "coma" después de la palabra 'contrato' en el inciso $2^{\circ}$ del artículo 1489 del $C C$., la cual deja en claro que la indemnización de perjuicios ahí prevista queda autorizada para el caso de pedirse la resolución como para el de pedirse el cumplimiento del contrato. La comparación da a entender que la ley quiso ligar la exhibición del título sólo con la notificación hecha por un notario, pero no con aquélla practicada judicialmente ${ }^{44}$. Con todo, el autor de la duda se inclina por aceptar que la ley en realidad pensó en exigir la exhibición en ambos tipos de notificación, fundado en la regla hermenéutica según la cual donde existe la misma razón debe existir la misma disposición, porque, en efecto, no se ve ninguna razón para establecer la diferencia ${ }^{45}$. Nosotros nos conformamos con este parecer; en refuerzo del cual sustraemos algo de la base textual que fundó la duda, porque, si bien es claro que la presencia de una "coma" después del término 'notario' hubiera dejado claro que la exhibición rige para ambas clases de notificación, su ausencia no es indicio necesario ${ }^{46}$, mas tan sólo posible, de que la exhibición vale sólo

${ }^{42}$ Cfr. el artículo $401 \mathrm{~N}^{\circ} 4 \mathrm{del}$ COT.: "Son funciones de los notarios: [...] $4^{\circ}$ Notificar los traspasos de acciones y constituciones [y notificaciones] de prenda que se les solicitaren". Que la expresión “y notificaciones” está demás en esta norma, es ostensible.

${ }^{43} \mathrm{La}$ proposición deriva de lo dispuesto por el artículo 400 inciso $4^{\circ}$ del COT.: "Ningún notario podrá ejercer sus funciones fuera de su respectivo territorio", que es una comuna.

${ }^{44}$ Así Elorriaga (n. 7), pp. 556-557.

${ }^{45}$ Ibid.

${ }^{46}$ La frase "judicialmente o por medio de un notario con exhibición del título" es intercalada entre: “[...] deberá ser notificada al deudor del crédito pignorado" y 
para la notificación notarial. En tales circunstancias, incluso, sin la "coma", es también posible que la exhibición valga también para la notificación judicial. Así que las cosas quedan en el estado inicial y, entonces, deben ser resueltas por una consideración estrictamente jurídica: no hay razón para establecer la diferencia que deviene, así, en arbitraria.

Concluimos, así, que la exhibición del título está exigida, sea que la notificación asuma la forma judicial, sea que asuma la forma notarial.

e) La misma norma, en cuanto exige la exhibición del título, sustenta una nueva duda, que esta vez radica en determinar si es necesario exhibir el título original o si basta la exhibición de sólo una copia de aquél. La razón de dudar proviene ahora de que la prenda de que trata el artículo 7 de la nueva ley es, por cierto, sin desplazamiento, así que no está prescrita la entrega del título original al pignoratario; lo cual vendría a quedar contradicho, empero, si es que deba exhibirse el título original al deudor, porque tal exhibición supondría la previa entrega del mismo al pignoratario -que es quien normalmente impulsa la notificación- para que, a su vez, lo ponga a disposición del receptor o del notario notificantes en función de ser exhibido por ellos al deudor. La contradicción desaparece, en cambio, cuando se entiende que la exhibición es sólo de una copia del título de aquélla a que se refiere el segundo segmento del artículo 7 inciso $1^{\circ}$, con estos términos, que examinaremos después con detalle ${ }^{47}$ :

"Una copia del título que consigne el crédito nominativo que se otorgue en prenda será protocolizada al tiempo de suscribirse el contrato de prenda y en éste deberá hacerse mención de la protocolización de aquél”.

El razonamiento descrito obliga a pensar que, en efecto, lo que debe exhibirse es una copia del título y no su original. El pignoratario no tiene facultades para exigir al pignorante el traspaso del original, ni siquiera bajo el pretexto de hacer ejecutar la notificación, ni el pignorante se encuentra obligado a entregárselo. Si fuera

"prohibiéndole [...]"; por lo cual es posible entender que el redactor consideró unitaria y totalmente la frase intercalada, con "coma" inicial y final, y que una nueva "coma" interpuesta entre "notario" y "con" hubiera debilitado la intercalación. No se transgrede ninguna regla gramatical cuando se lee holísticamente la frase intercalada.

${ }^{47}$ Así Elorriaga (n. 7), pp. 553-554. 
lo contrario, la ley algo pertinente hubiera estatuido y no hubiese dejado tan importante asunto librado al pasar y a la deducción; así que la frase: "con exhibición del título" la entendemos como si dijera: "con exhibición 'de una copia' del título".

f) El inciso $1^{\circ}$ del artículo 7 indica que la notificación del contrato prendario al deudor del crédito pignorado debe portar consigo una simultánea "prohibición"; pues dice:

"La prenda de créditos nominativos deberá ser notificada al deudor del crédito pignorado, [...], prohibiéndole que lo pague en otras manos 'que las del acreedor prendario' [...]”.

Damos, entonces, su pleno valor al gerundio 'prohibiéndole', cuya función es expresar la simultaneidad de dos acciones; en el caso, de la notificación y de la prohibición de pagar en otras manos. Lo cual quiere decir que es necesario expresar al deudor precisamente que le queda prohibido pagar en otras manos. La única manera de entender esto, es que el receptor o el notario notificantes deben advertir aquello al deudor junto con notificarle el contrato prendario y exhibirle la copia del título del crédito pignorado.

Pero que el deudor no deba pagar el crédito al acreedor deriva, no de la concreta prohibición que le es proferida junto con la notificación y la exhibición, sino de una restricción formulada por la ley ${ }^{48}$. Es, en efecto, el propio artículo 7 inciso $1^{\circ}$ de la nueva ley ${ }^{49}$ la que impide al deudor pagar en otras manos que no sean las del pignoratario; sólo que, en obsequio y ayuda al deudor, la norma exige, para hacerse operativa, que se diga en concreto al deudor, que le queda prohibido (por mandato de la ley) hacer tal pago.

Por consiguiente, es la naturaleza legal de la prohibición dirigida al deudor de pagar en otras manos que no sean las del pignoratario la que explica que el pago hecho al acreedor sea nulo absolutamente $^{50}$. El, en efecto, contraviene al artículo 1466 del $C C$., que declara haber objeto ilícito "en todo contrato prohibido por las leyes", donde el vocablo 'contrato' lo interpretamos en el sentido habitual de "acto o contrato", de modo de abrazar también al acto del pago.

4. La operación prevista en el primer segmento del artículo 7 inciso $1^{\circ}$ es compleja, ya que consiste en notificar el contrato prendario al deudor,

\footnotetext{
${ }^{48}$ Conforme Elorriaga (n. 7), p. 557.

${ }^{49} \mathrm{Y}$ antes el artículo 2389 del $C C$. para la prenda civil de créditos.

${ }^{50}$ Conforme Elorriaga (n. 7), pp. 553-554.
} 
exhibirle una copia del título del crédito pignorado y advertirle que no debe pagarlo en otras manos. Ahora bien, la omisión de cualquiera de estos tres extremos o la incidencia de defectos en ellos generan, no nulidad absoluta, sino mera inoponibilidad al deudor. Lo dice la frase final de ese primer segmento: una vez descrita la operación compleja que acabamos de resumir, la norma añade después del signo de "punto y coma": "y en caso contrario, le será inoponible". El sujeto de esta frase, por lo demás rector de todo el segmento, es: "La prenda de créditos nominativos", que, en realidad, como quedó dicho, significa: "el contrato de prenda de créditos nominativos"; el pronombre personal, bajo forma de complemento indirecto, 'le' va referido al "deudor del crédito pignorado", que es quien puede invocar, por consiguiente, la inoponibilidad; el "caso contrario", en fin, atañe:

i) a la ausencia de notificación del contrato prendario; o

ii) a la ausencia de exhibición del título del crédito pignorado; o

iii) a la ausencia de prohibición de pagarlo en otras manos.

Cualquiera de estas hipótesis es caso contrario y en cualquiera de ellas se genera inoponibilidad del contrato prendario al deudor.

5. La notificación del contrato prendario, unida a la exhibición de una copia del título en que conste el crédito pignorado y a la prohibición de pagarlo en otras manos que las del pignoratario no es necesaria cuando el deudor previamente había aceptado por escrito la prenda. Dice la norma:

"La prenda de créditos nominativos deberá ser notificada al deudor del crédito pignorado, [...], salvo que [mediare ${ }^{51}$ 'hubiera mediado' ${ }^{52}$ su aceptación por escrito".

Si consta que el deudor aceptó la prenda, es, en efecto, superfluo y redundante notificársela, porque debe entenderse que ya la conoce. Por consiguiente, la aceptación de la prenda por parte del deudor del crédito pignorado hace que aquélla le sea, sin más, oponible.

a) La prenda es un acto jurídico que consiste en la declaración solemne de voluntad concorde del pignorante y el pignoratario, en orden a afectar cosas muebles a garantía de una obligación, y no requiere "aceptación" de terceros para su perfección. Esto vale

${ }^{51}$ Así en el texto legal; pero véase la nota siguiente.

${ }^{52}$ En la hipótesis tratada por el artículo 7 inciso $1^{\circ}$, el tiempo presente está fijado en el momento en que se examina la necesidad de notificar el contrato prendario al deudor. Para decidir si es ella necesaria, antes tiene que haber mediado la aceptación. Por consiguiente, el uso de la forma 'mediare' resulta incorrecto en el texto, porque es de futuro: no se trata de si haya de mediar, mas de si ha mediado. 
también para la prenda de créditos nominativos. En especial, no es requisito del acto prendario que el deudor del crédito pignorado lo acepte. La deslegitimación del deudor para pagar y del acreedor para recibir el pago en rigor tampoco depende de que el deudor "acepte" la prenda, pues cuando así fuere, su aceptación hubiera sido exigida siempre; pero no lo es si interviene notificación. En realidad ésta es la regla general. Pero la notificación es sólo un medio para dar conocimiento, y no para recibir la expresión de algún consentimiento ${ }^{53}$. Estas premisas tornan en sospechoso el vocablo 'aceptación' usado en la norma, si se lo entiende en el sentido de una voluntad dirigida a manifestar "aprobación", "consentimiento", "consenso, "asenso", "beneplácito", "conformidad", "permiso", etc. Lo que la ley pide es que el deudor conozca que el crédito de que es deudor fue pignorado; no que acepte la pignoración, porque, aunque no la acepte o apruebe, etc., si sabe que existe, es lícito negarle valor al pago que haga al acreedor. Dicho vocablo fue mal empleado en la ley y procede interpretarlo en el sentido (por lo, demás original y natural) de 'recibir' (accipere), que podemos entender como "recibir la noticia o el dato o el hecho" de haber habido pignoración de guisa de reconducir la figura a su genuina naturaleza de acto de conocimiento ${ }^{54}$.

b) Por razones de seguridad, la ley exige que la "recepción" de la prenda por el deudor, vale decir, su conocimiento de existir, conste por escrito. Es indiferente que el escrito date con precedencia o con posterioridad al perfeccionamiento del contrato prendario, $o$ que sea coetáneo con él, si sirve de prueba para el hecho de que el deudor no desconoció la pignoración, mérito éste que el juez debe ponderar en conformidad con las reglas generales.

c) Si se invoca un escrito así, no es necesario probar que el deudor conoció el título del crédito pignorado y que le fue prohibido pagarlo en otras manos que las del pignoratario. Alguien podría, en efecto, aducir que el acto exigido por el primer segmento del artículo 7 inciso $1^{\circ}$ de la ley es complejo, como de hecho lo es, por constar de una notificación, una exhibición y una prohibición;

${ }^{53}$ Cfr. el artículo 39 del CPC.: "Para la validez de la notificación no se requiere el consentimiento del notificado".

${ }^{54}$ Obsérvese la siguiente paradoja: supóngase que un deudor, creyendo tal vez que la validez de la pignoración del crédito de que es deudor, exige su anuencia, para entorpecerla escribe al pignoratario que "no acepta la prenda celebrada por escritura pública de tal fecha”. El escrito puede ser invocado por el pignoratario para oponer la prenda al deudor, porque con él manifiesta que la conoció, por más que haya dicho ahí que no la aceptaba. 
y que la manifestación escrita de aceptación suple sólo la notificación, de modo que, además de tal manifestación, todavía cabe exigir la exhibición y la prohibición. Pero esta interpretación tiene notorios visos de ser absurda, por cuanto no se sabría cómo dar cumplimiento a esas exigencias. La ley se contenta con el escrito de aceptación; la salvedad que pronuncia ("salvo que [...]"), atañe a todo el período anterior:

"La prenda de créditos nominativos deberá ser notificada al deudor del crédito pignorado, judicialmente o por medio de un notario con exhibición del título, prohibiéndole que lo pague en otras manos [...]",

y no únicamente a la frase:

"La prenda de créditos nominativos deberá ser notificada al deudor del crédito pignorado, judicialmente o por medio de un notario".

Por lo demás, si alguien manifiesta conocer la prenda de un crédito de que es deudor, la ley entiende que conoce el título. En fin, como, según vimos ${ }^{55}$, la prohibición de pagar el crédito en otras manos que las del pignoratario es legal, el deudor que conoce la pignoración no puede alegar que desconoce saber que merced a ella no debe pagar en manos diversas a las del pignoratario.

\section{INOPONIBILIDAD DE LA PIGNORACIÓN DE UN CRÉDITO NOMINATIVO A TERCEROS}

De acuerdo con la regla general sentada por el artículo 25 inciso $1^{\circ}$ de la nueva ley ${ }^{56}$, la prenda de un crédito es oponible a terceros desde la fecha en que el contrato prendario sea inscrito en el Registro de Prendas sin Desplazamiento. Al efecto, es indiferente que ese contrato haya sido notificado al deudor del crédito pignorado o que no lo haya sido, porque tal notificación es requisito de oponibilidad de la pignoración al deudor del crédito precisamente, mas no a los terceros ${ }^{57}$.

${ }^{55}$ Más arriba, vI, 3, f).

${ }^{56}$ Artículo 25: "El derecho real de prenda se adquirirá, probará y conservará por la inscripción del contrato de prenda en el Registro de Prendas sin Desplazamiento. La prenda sólo será oponible a terceros a partir de esa fecha”.

${ }^{57}$ Conforme Elorriaga (n. 7), pp. 555-556. 
Pero la prenda sin desplazamiento de un crédito nominativo sí puede resultar inoponible a terceros, aunque no como consecuencia de alguna norma especial dada para ella, sino por aplicación singular de ciertas norma generales sobre inoponibilidad a aquéllos establecidas en la ley.

Por regla general, esta inoponibilidad a terceros genera el efecto de tornar en inoperante el privilegio prendario del pignoratario frente a esos importantes terceros que son los demás acreedores; y en neutralizar la vindicación pignoraticia o persecución del crédito merced al derecho real de prenda que lo grava; todo lo cual inutiliza la garantía.

a) $\mathrm{El}$ inciso $2^{\circ}$ del artículo 25 dice:

"En caso de bienes sujetos a inscripción obligatoria en algún otro registro, la prenda será inoponible a terceros, mientras no se anote una referencia del contrato de prenda al margen de la inscripción correspondiente".

Esta norma resulta aplicable a la pignoración de un crédito nominativo en la medida en que el crédito de que se trate esté sujeto a inscripción obligatoria en algún otro registro, de guisa que deba anotarse una referencia del contrato de prenda sobre el crédito al margen de la inscripción de éste en el registro que corresponda.

Entre otros posibles, son créditos sujetos a inscripción obligatoria: i) Los que adopten la forma de títulos-valores regidos por la ley $\mathrm{N}^{\mathrm{O}}$ 18.045 , de 1981, sobre Mercado de valores ${ }^{58}$. En tal caso están las opciones de compra y venta de acciones, los bonos y debentures, las cuotas de fondos mutuos, los planes de ahorro y, en general -dice la ley-, todo título de crédito e inversión (artículo 3). Las emisiones de oferta pública de estos valores y los valores mismos deben ser inscritos, en efecto, en un registro de valores que administra y gestiona la Superintendencia de Valores y Seguros (artículo 5). Por su parte, los valores extranjeros y los certificados de depósito de tales se inscriben en un registro de valores extranjeros que administra la misma Superintendencia (artículo 183).

ii) Los títulos de deuda emitidos por las sociedades securitizadoras, que deben ser inscritos en el Registro de Valores de acuerdo con el artículo 134 inciso $1^{\circ}$ de la antes citada ley $N^{\circ} 18.045$, de 1981, sobre Mercado de valores ${ }^{59}$.

El defecto de anotación de una referencia del contrato de prenda de estos créditos al margen de su inscripción en el correspondiente

\footnotetext{
58 Diario Oficial, 22 de octubre de 1981.
}

${ }_{59}$ Véase la nota anterior. 
registro especial hace inoponible la prenda a terceros, como lo expresa el artículo 25 inciso $2^{\circ}$.

b) El inciso $3^{\circ} \mathrm{del}$ artículo 25 agrega la siguiente hipótesis general de inoponibilidad de la prenda a terceros:

"Sin embargo, el derecho de prenda no será oponible contra el tercero que adquiera el bien empeñado por venta al detalle en una fábrica, feria, bolsa de productos agropecuarios, casa de martillo, tienda, almacén u otros establecimientos análogos en que se vendan cosas muebles de la misma naturaleza".

Para el detalle dogmático de esta norma remitimos a otro lugar ${ }^{60}$. Puesto que los créditos pueden ser adquiridos como contrapartida de una venta al detalle en establecimientos análogos a los mentados en la norma, como son las bolsas de valores o las casas de martillo, si acaeciera haber sido previamente pignorados sin desplazamiento, el correspondiente derecho real de prenda que exista no será oponible al comprador.

c) El inciso $1^{\circ}$ del artículo 13 de la ley expresa:

"Sólo el dueño podrá alegar la inexistencia del derecho real de prenda invocando su derecho de dominio sobre la cosa pignorada, sin perjuicio de la validez del contrato".

De acuerdo con esta norma, la pignoración de un crédito por quien no es su acreedor ${ }^{61}$ le es inoponible ${ }^{62}$.

d) De ciertas inoponibilidades especiales habremos de tratar en el capítulo siguiente.

\section{Pignoraciones ESPECIALES DE CRÉditos NOMinativos}

La propia ley prevé la pignoración sin desplazamiento de determinado tipo de créditos que, por consiguiente, toma el carácter de especial con respecto a la general de créditos nominativos del artículo 7.

${ }^{60}$ Véase GuZMán Brito (n. 29), pp. 127-129.

${ }^{61}$ Véase más arriba, el capítulo III.

${ }^{62}$ Véase Alejandro GuZMÁn BRITo, "Las prendas ordinaria y sin desplazamiento de la Ley No 20.190 recaídas en cosa ajena", en Fabricio Mantilla EsPinoza - Carlos Pizarro Wilson (coordinadores), Estudios de Derecho privado en homenaje a Christian Larroumet, Santiago - Bogotá, Universidad Diego Portales, Fundación Fernando Fueyo - Universidad del Rosario, 2008, pp. 401-422. 
a) Desde luego, el artículo 7 mismo, después de haber descrito en su inciso $1^{\circ}$ el régimen que ahora estudiamos, añade en su inciso $2^{\circ}$ :

"Las obligaciones contenidas en este artículo no serán aplicables a las prendas constituidas sobre los derechos señalados en el artículo $6^{\circ \%}$.

En general, el citado artículo 6 atañe a la prenda sin desplazamiento de seis derechos de concesión y de una de derechos que para el participante emanen del contrato de participación celebrado conforme a la ley $\mathrm{N}^{\circ}$ 19.865. Los derechos principalmente pignorables en conformidad con ese artículo no son de créditos, sino reales administrativos; pero su pignoración cubre algunos créditos de la concesión o la participación, en cuanto accesorios suyos. Ahora bien, como se habrá observado, el inciso $2^{\circ}$ del artículo 7 hace inaplicables las cargas y los requisitos prescritos en su inciso $1^{\circ}$ (que denomina "obligaciones") para la prenda de créditos nominativos a las pignoraciones de concesiones y de derechos de participación concluidas merced al artículo 6 en cuanto abracen pignoraciones de créditos nominativos.

b) El inciso $1^{\circ}$ del artículo 8 de la nueva ley atañe a la prenda de valores desmaterializados, porque carecen de título, que es sustituido por una "anotación en cuenta", de donde resulta que también se los conozca como "valores sin impresión física del título que los evidencia" ${ }^{63}$. Ahora bien, algunos de estos calores pueden consistir en créditos nominativos. Ellos siguen bajo la posibilidad de ser pignorados sin desplazamiento, con sometimiento a las reglas generales de tal pignoración; pero es claro que ella no puede ser, además, regida por el artículo 7 de la nueva ley, en cuanto éste exige la protocolización del título del crédito pignorado y la exhibición de una copia del mismo al deudor al tiempo de notificarle el contrato prendario, porque de partida no hay título que admita protocolización y exhibición. Por ello, las reglas del artículo 8 que gobiernan la prenda de todos los valores desmaterializados se aplican también a este mismo tipo de créditos nominativos, en cuanto también sean tales valores ${ }^{64}$; así que una vez más estamos

${ }^{63}$ Sobre la materia, véase Alejandro GuZMán BRITO, "La prenda de valores emitidos sin impresión física del título que los evidencie” (en prensa).

${ }^{64}$ Artículo 8 inciso $1^{\circ}$ : "Los valores emitidos sin impresión física del título que los evidencie, podrán ser prendados bajo las disposiciones de la presente ley, en cuyo caso 
ante una pignoración parcialmente especial de créditos nominativos.

c) El mismo artículo 8, en su inciso $2^{\circ 65}$, alude a la prenda de valores depositados en una empresa de depósito de valores constituida en los términos de la ley $\mathrm{N}^{\circ} 18.876$, de 1989, que Establece el Marco Legal para la Constitución y Operación De Entidades Privadas de Depósito y Custodia de Valores ${ }^{66}$. Esta prenda sin desplazamiento de valores depositados en empresas de depósito de valores se constituye en la manera ordinaria de tal prenda y se inscribe en el Registro de Prenda sin Desplazamiento (a lo cual atañe la referencia del inciso $3^{\circ}$ del artículo 8 al "título IV de la presente ley"); pero, además, debe ser anotada en el registro de valores depositados, que gestiona la empresa misma.

Pero los créditos nominativos, consten o no en títulos, son valores (titulados o, bien, desmaterializados). Si están depositados en una empresa de depósito, su pignoración se rige, además, por lo señalado en este inciso $2^{\circ}$. Es otro caso de una prenda parcialmente especial de créditos nominativos.

d) El artículo 14 de la ley $\mathrm{N}^{\mathrm{O}}$ 18.876, de 1989, que Establece el Marco Legal para la Constitución y Operación de Entidades Privadas de Depósito y Custodia de Valores ${ }^{67}$, regula una prenda de valores, con o sin título, depositados en empresas de depósito, que es distinta a la supuesta en el artículo 8, siempre sin desplazamiento, porque aquélla opera merced a un certificado de la cantidad de valores depositados, que debe emitir la empresa de depósito, y que reemplaza al título representativo del valor de que se trate, así que puede ser con o sin desplazamiento, a elección de las partes del contrato prendario ${ }^{68}$. Ahora bien, si el valor depositado es un

la prenda deberá anotarse en el registro de anotaciones en cuenta que se lleve para estos efectos".

${ }^{65}$ Artículo 8 inciso $2^{\circ}$ : "Tratándose de valores depositados en una empresa de depósito de valores constituida de acuerdo a la ley $\mathrm{N}^{\circ} 18.876$, el acreedor prendario podrá solicitar la anotación de la prenda directamente a dicha empresa".

${ }^{66}$ Diario Oficial, de 21 de diciembre de 1989.

${ }^{67}$ Ibid.

${ }^{68}$ Artículo 14 de la ley $\mathrm{N}^{\mathrm{o}}$ 18.876, de 1989: “[Inciso $1^{\circ}$ ] El depositante puede constituir prendas y derechos reales sobre los valores que tenga depositados, en los mismos casos en que podría hacerlo si no estuvieren en depósito. [Inciso $2^{\circ}$ ] Para este efecto, a solicitud del depositante la empresa de depósito le entregará un certificado de los que se refiere el artículo anterior, que acredite la cantidad de valores que tiene depositados. A solicitud del depositante el certificado puede restringirse a sólo parte de los valores que tenga entregados en depósito. [Inciso $3^{\circ}$ ] Si el depositante declarare que el depósito lo efectuó a su propio nombre, pero por cuenta de un tercero, la empresa de depósito emitirá los 
crédito nominativo y consta en un título, cuando se lo pignora sin desplazamiento, el certificado antes aludido actúa en vez del título para efectos de su protocolización y exhibición en los términos del artículo 7 . Además, el inciso $5^{\circ}$ del artículo 14 en examen prevé la notificación de la prenda por un notario a la empresa de depósito, bajo carga de su inoponibilidad a ésta y a terceros:

“Cualquiera que sea la clase de prenda [...], no será oponible a la empresa de depósito ni a terceros, mientras no haya sido notificada a esa empresa por un notario, sin perjuicio de las demás formalidades que procedan de acuerdo a la ley".

Los respectos señalados, entonces, constituyen especialidades de esta prenda sin desplazamiento.

e) En sus incisos $1^{\circ}$ a $3^{\circ}$ del artículo 11 , la nueva ley contiene reglas de fondo sobre la pignoración de grupos de bienes de una misma clase o universalidades de hecho ${ }^{69}$. Por cierto, los créditos nominativos de la misma clase pueden ser considerados como un grupo de tales créditos o una universalidad de créditos; y pignorados en cuanto conjuntos así. Nada obsta, por ejemplo, a que una empresa constituya en prenda de aquella manera su cartera de créditos. Por consiguiente, las reglas generales de la ley sobre prenda de créditos nominativos contenidas en su artículo 7 son aplicables tanto si el objeto prendado sea un crédito singular como cuando lo sea un conjunto universal de tales créditos. En este último caso, las reglas de fondo del artículo 11 incisos $1^{\circ}$ a $3^{\circ}$ rigen el funcionamiento de la prenda ya constituida; mientras que su constitución se habrá debido sujetar a las generales del artículo 7, más a la especial, aplicable al contrato de prenda sobre conjuntos, contenida en el inciso $4^{\circ}$ del artículo 11 , que obliga a ciertas menciones en él ${ }^{70}$.

certificados de que tratan el artículo 13 y el presente artículo a nombre de quien le indique el depositante, bajo exclusiva responsabilidad de éste. [Inciso $4^{\circ}$ ] Para los efectos de las formalidades necesarias para la constitución de la prenda u otro derecho real, el certificado reemplazará al título representativo del valor de que se trate. [Inciso $5^{\circ}$ ] Cualquiera que sea la clase de prenda o de derecho real, no será oponible a la empresa de depósito ni a terceros, mientras no haya sido notificada a esa empresa por un notario, sin perjuicio de las demás formalidades que procedan de acuerdo a la ley [...]".

${ }^{69}$ Sobre ella, véase Alejandro GuZmán Brito, "La pignoración de grupos de bienes de una misma clase o universalidades de hecho en la nueva Ley de prenda sin desplazamiento", en Revista de Derecho de la Pontificia Universidad Católica de Valparaíso, No 30 , Valparaíso, $1^{\text {er }}$ semestre de 2008, pp. 61-153.

${ }^{70}$ Artículo 11 inciso $4^{\mathrm{o}}$ : "Cuando se pignoraren universalidades o grupos de bienes en la forma señalada en el inciso primero, el contrato de prenda deberá indicar el valor 


\section{Delitos COMETidos CON OCASIÓN \\ DE LA PRENDA DE CRÉDITOS NOMINATIVOS}

El artículo 39 de la nueva ley ofrece la descripción de cinco tipos penales prendarios. Cuatro de ellos, salvo ciertos aspectos de uno, son aplicables por subsunción a la prenda de créditos nominativos; y por mención expresa el quinto. De estos delitos hemos tratado en general en otro lugar, al cual nos remitimos, así que en el presente nos limitaremos a ciertas aplicaciones ${ }^{71}$.

a) Se aplican sin más a la prenda de créditos nominativos los tres tipos del artículo $39 \mathrm{~N}^{\circ}$, consistentes en:

i) "el que defraudare a otro disponiendo de las cosas constituidas en prenda en conformidad a esta ley, sin señalar el gravamen que las afecta",

como cuando se cede un crédito pignorado sin dar a conocer el gravamen que lo afecta al cesionario;

ii) "el que defraudare a otro [...] constituyendo prenda sobre bienes ajenos como propios", como si un tercero pignora el crédito de otro y

iii) "el que defraudare a otro [...] alzando la prenda que haya cedido", fórmula ésta que se debe entender como si se hubiera escrito: "el que defraudare a otro [...] alzando la prenda que garantizaba el crédito que haya cedido", como si un acreedor, cuyo crédito le había sido garantizado con otro crédito, cede aquél y alza su prenda garantizadora, perjudicando al cesionario.

b) Por lo que atañe al tipo del artículo $39 \mathrm{~N}^{\circ} 2$, que reza:

"El deudor prendario y el que tenga en su poder la cosa constituida en prenda en conformidad a esta ley que, defraudando al acreedor prendario, la altere, oculte, sustituya, traslade o disponga de ella",

del conjunto de bienes sobre los que recaiga la prenda, salvo que las partes acuerden expresamente no asignarle un valor. En este último caso, no será aplicable lo dispuesto en el artículo 1496, $\mathrm{N}^{\circ}$ 2, del Código Civil y el contrato de prenda deberá señalar las particularidades tendientes a individualizar los bienes prendados, señalando si son fungibles o no, determinando en el primer caso su especie, cantidad, calidad, graduación y variedad". Sobre el significado de esta disposición, véanse los capítulos XVI al XVIII del trabajo citado en la nota anterior, pp. 127-143

${ }^{71}$ Véase Alejandro Guzmán Brito, "Delitos cometidos con ocasión de una prenda sin desplazamiento" (en prensa). 
puede ser cometido en tanto las conductas de alterar, ocultar, sustituir, trasladar o disponer sean compatibles con el carácter incorporal del crédito, que es objeto de la pignoración. De esta guisa, no cabe pensar en acciones materiales o físicas consistentes en alterar, ocultar, sustituir o trasladar aplicadas al crédito; pero sí en aquéllas consistentes en disponerlo jurídicamente, como cuando el acreedor del crédito, que es su pignorante o deudor prendario, lo extingue de manera fraudulenta en perjuicio del pignoratario. No debe confundirse la imposibilidad de atacar el crédito con actos materiales y la posibilidad de disponerlo merced a actos materiales: si el acreedor de una especie, la destruye, su crédito se extingue (artículo 1670 del $C C$.); si ese crédito había sido dado en prenda, la prenda misma se extingue por aquella destrucción (artículo 2406 inciso $1^{\circ} \operatorname{del} C C$.). El acto material de destrucción no pudo afectar al crédito sino a la cosa en crédito; pero como la destrucción de ésta, por efecto del Derecho, produjo la extinción del crédito, en la apariencia hace que el delito del artículo $39 \mathrm{~N}^{\circ} 2$ quede cometido por el pignorante, pues le es imputable. Pero ello es sólo teórico y por ello aparente, ya que, en la realidad, una conducta así más queda incluida en el tipo del artículo $39 \mathrm{~N}^{\circ} 3$, que es especial.

c) En efecto, el tipo del artículo $39 \mathrm{~N}^{\circ} 3$ está formulado con expresa referencia a la prenda de créditos nominativos:

"El deudor prendario que, tratándose de prendas de créditos [...] constituidos en prenda en conformidad a esta ley, defraude al acreedor prendario, ocasionando la pérdida o el menoscabo de los derechos otorgados en garantía”.

Se trata de proteger al crédito garantizado contra las conductas del deudor prendario (y se omitió al tercero que confirió prenda por deudas ajenas ${ }^{72}$. La criminalización de esta conducta encuentra su correlato civil en el artículo 18 inciso $3^{\circ}$ :

“Tratándose de derechos, el constituyente estará obligado a evitar su menoscabo o extinción. En caso de infracción a lo dispuesto precedentemente, la obligación caucionada se considerará como de plazo vencido. Lo anterior es sin perjuicio de las demás respon-

\footnotetext{
${ }^{72}$ Así que cuando el hecho sea perpetrado por el acreedor que había salido como pignorante para garantizar deudas ajenas, y resulte subsumible en el tipo del artículo 39 $\mathrm{N}^{\circ} 2$, en cuanto atañe a: "el que tenga en su poder la cosa constituida en prenda", cuyo es el caso, podrá ser perseguido bajo este concepto.
} 
sabilidades [...] penales que correspondan como consecuencia [...] del menoscabo o extinción de los derechos prendados".

Las conductas del deudor prendario que lesionan al pignoratario son aquéllas que tienen por resultado la extinción total o parcial del crédito, porque correlativamente se extingue o se rebaja la prenda. Podría acaecer, en efecto, que el pignorante de un crédito suyo lo novara, transara o remitiera o, bien, que resciliara el negocio jurídico del cual emana el crédito; o que lo dejara prescribir a sabiendas; o que se hiciera dolosamente deudor de su deudor a fin de compensar el crédito pignorado; o, en fin, que recibiera de su deudor el pago después de haber sido notificada a éste la pignoración, como ordena el artículo 7 de la ley. En todos esos eventos, y en otros, acontece que el crédito empeñado se pierde o se menoscaba y queda, por ende, cometido el delito. Se observará que, como quedó adelantado, el caso descrito en la letra $b$ ) precedente cae con mayor especificidad bajo este tipo.

Pero hay un problema. La prenda de un crédito nominativo, notificada a su deudor con exhibición del título y prohibición de pagarlo en otras manos que las del pignoratario, suspende la legitimación del acreedor-pignorante para exigir el cumplimiento del crédito al deudor y para recibir de éste su pago. Pero esa misma deslegitimación afecta a todas las facultades dispositivo-jurídicas del acreedor, quien, por ende, no puede ceder el crédito empeñado, ni novarlo, transarlo o remitirlo; incluso quedan impedidas la compensación ${ }^{73}$ y la confusión ${ }^{74}$. En tales circunstancias, los actos dispositivo-jurídicos del acreedor-pignorante (= deudor prendario), que en otras circunstancias extinguirían el crédito, como la novación por cambio de acreedor o la remisión, etc., no valen con respecto al crédito pignorado, así que su ejecución no puede defraudar ni perjudicar al pignoratario y el delito se hace imposible en muchas hipótesis. Pero no necesariamente en todas, como en el de la destrucción de la cosa debida.

${ }^{73}$ Merced al artículo 1661 inciso $1^{\circ}$ del $C C$, porque perjudicaría los derechos del pignoratario.

${ }^{74} \mathrm{Si}$ muere el deudor, quien había instituido como heredero a su acreedor, el cual tenía pignorado el crédito contra aquél, éste no se extingue por confusión y el pignoratario puede cobrarlo contra el acreedor, que ahora es deudor hereditario. Esto, que es de toda lógica, puede ser apoyado exegéticamente en la parte final del artículo 1665 del $C C$., que de la confusión dice producir: "iguales efectos que el pago". Por consiguiente, si la prenda de un crédito (debidamente notificada, etc.) impide que se pague al acreedor, también debe impedir que se produzca una confusión que equivalga a que se le hubiera pagado. 


\section{BibLIOGRAFÍA}

Abeliuk, René, Las obligaciones, $3^{\mathrm{a}}$ ed., Santiago, Editorial Jurídica de Chile, 1993.

Bello, Andrés, Obras completas de don Andrés Bello, Santiago, impreso por Pedro G. Ramírez, 1890, tomo XIII: Proyecto Inédito de Código Civil.

Code Civil, 107 ed., Paris, Dalloz, 2008.

Codice Civile, aggiornato alla Gazzetta Ufficiale di 31 dicembre 1996, Roma, Società Editrice de "Il Foro Italiano", 1997.

Código Civil de la República de Chile.

Código de Aguas de 1982.

Código de Comercio de la República de Chile.

Código Orgánico de Tribunales.

Decreto-ley N N $^{\circ} 76$, en Diario Oficial, 22 de diciembre de 1925.

ElorRiaga, Fabián, "La prenda de créditos nominativos en la nueva normativa de la prenda sin desplazamiento", en Carlos Pizarro WiLson (coordinador), Estudios de Derecho Civil, Iv: Jornadas Nacionales de Derecho Civil, Olmué, 2008, Santiago, LegalPublishing, 2009.

Guzmán Brito, Alejandro, "Delitos cometidos con ocasión de una prenda sin desplazamiento" (en prensa).

GuZMÁn BRito, Alejandro, "El derecho real de prenda sin desplazamiento", en Revista de Derecho de la Pontificia Universidad Católica de Valparaíso, $\mathrm{N}^{\mathrm{O}} 34$, Valparaíso, ${ }^{\text {er }}$ semestre de 2010.

GuZMÁn BRITo, Alejandro, "El llamado contrato de prenda sin desplazamiento", en Revista Chilena de Derecho Privado "Fernando Fueyo Laneri", No 13, Santiago, diciembre de 2009.

GuZmán Brito, Alejandro, "La indivisibilidad de la garantía prendaria e hipotecaria", en Carlos Pizarro Wilson (coordinador), Estudios de Derecho Civil, IV: Jornadas Nacionales de Derecho Civil, Olmué, 2008, Santiago, LegalPublishing, 2009.

GuZmán Brito, Alejandro, "La pignoración de grupos de bienes de una misma clase o universalidades de hecho en la nueva Ley de prenda sin desplazamiento", en Revista de Derecho de la Pontificia Universidad Católica de Valparaíso, $\mathrm{N}^{\mathrm{o}} 30$, Valparaíso, $1^{\mathrm{er}}$ semestre de 2008.

GuZmán Brito, Alejandro, "La prenda de valores emitidos sin impresión física del título que los evidencie" (en prensa).

GuZMán BRIto, Alejandro, "La prenda sin desplazamiento de cosas corporales e incorporales futuras", en Revista de Derecho de la Pontificia Universidad Católica de Valparaíso, $\mathrm{N}^{\mathrm{O}} 31$, Valparaíso, $2^{\circ}$ semestre de 2008.

GuZmán BRITo, Alejandro, "Las prendas ordinaria y sin desplazamiento de la Ley No 20.190 recaídas en cosa ajena”, en Fabricio Mantilla Espinoza - Carlos 
Pizarro Wilson (coordinadores), Estudios de Derecho privado en homenaje a Christian Larroumet, Santiago - Bogotá, Universidad Diego Portales, Fundación Fernando Fueyo - Universidad del Rosario, 2008.

GuZmán Brito, Alejandro, Las cosas incorporales en la doctrina en el Derecho positiva, $2^{\mathrm{a}}$ ed., Santiago, Editorial Jurídica de Chile, 2006.

Ley N ${ }^{\circ}$ 20.190, que Dicta Normas Sobre Prenda sin Desplazamiento y Crea el Registro de Prendas sin Desplazamiento, en Diario Oficial, de 5 de junio de 2007.

Ley $\mathrm{N}^{\circ}$ 18.045, de 1981, sobre Mercado de Valores, en Diario Oficial, 22 de octubre de 1981.

Ley $N^{\circ}$ 18.092, que Dicta Nuevas Normas Sobre Letra de Cambio y Pagaré, en Diario Oficial, de 14 de enero de 1982.

Ley No 18.112 , que Dicta Normas Sobre Prenda sin Desplazamiento, en Diario Oficial, de 16 de abril de 1982.

Ley No 18.552, que Regula Tratamiento de los Títulos de Crédito, en Diario Oficial, de 20 de septiembre de 1986.

Ley $\mathrm{N}^{\mathrm{O}}$ 18.876, de 1989, que Establece el Marco Legal para la Constitución y Operación de Entidades Privadas de Depósito y Custodia de Valores, en Diario Oficial, de 21 de diciembre de 1989.

Proyecto de Código Civil, Santiago, Imprenta Nacional, noviembre de 1855.

"Reglamento del Registro de Prenda sin Desplazamiento", contenido en el decreto supremo $\mathrm{N}^{\circ} 722$, de 8 de septiembre de 2010, del Ministerio de Justicia, publicado en el Diario Oficial, de 23 de octubre de 2010.

Somarriva, Manuel, Tratado de las cauciones, $2^{\text {a }}$ ed., Santiago, Contable Chilena, 1983. 